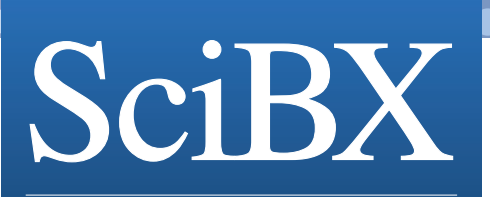

THE DISTILLERY

$\overline{\text { Science-Business eXchange }}$

This week in therapeutics

\section{Target/marker/ \\ Musculoskeletal disease}

Bone repair

Wnt

\section{Summary}

Studies in mice suggest that mesenchymal stem cells overexpressing Wnt could be useful for increasing bone formation to help heal bone fractures. In a mouse model of ectopic bone formation, implants of Wnt-overexpressing human mesenchymal stem cells mixed with hydroxyapatite (HA)/tri-Ca phosphate (TCP) ceramic powder increased bone formation by up to $25 \%$ compared with that seen in controls that overexpressed control LacZ protein. Next steps could include testing the approach in animal models of fracture repair.

SciBX 2(15); doi:10.1038/scibx.2009.632 Published online April 16, 2009

\section{Licensing} status

Patent application filed; unlicensed

\section{Publication and contact information}

Liu, G. et al. J. Cell Biol.; published online April 6, 2009; doi:10.1083/jcb.200810137

Contact: Stuart A. Aaronson, Mount Sinai School of Medicine, New York, N.Y.

e-mail:

stuart.aaronson@mssm.edu 